\title{
Evolution of hereditary non-polyposis colorectal
}

\section{cancer}

\author{
J R Jass, S M Stewart
}

\begin{abstract}
The prevalence of colorectal adenoma in 23 affected patients with hereditary non-polyposis colorectal cancer (HNPCC) was compared with that in an age matched forensic autopsy population. The mean ages at diagnosis of colorectal cancer in men (13) and women (10) were 39 and 37 years respectively. In HNPCC patients who presented below the age of 50 years, at least one adenoma was found in $\mathbf{3}$ of $10(30 \%)$ men and in 4 of $9(44 \%)$ women. In the age matched autopsy specimens of large bowel, a solitary adenoma was found in $2 / 42(5 \%)$ men $(p=0.015)$ and $1 / 21 \quad(5 \%)$ women $(p=0.0075)$. Of the 11 adenomas from HNPCC patients, nine were greater than $1 \mathrm{~cm}$ and six showed a pure villous architecture. Contiguous adenocarcinoma was observed with six adenomas. Adenomas do not occur in large numbers in HNPCC, but develop at a young age, attain a large size, often show a villous configuration, and are more prone to malignant conversion than sporadic adenomas.
\end{abstract}

Evidence is accumulating that hereditary nonpolyposis colorectal cancer (HNPCC) is a distinct clinicopathological entity. ${ }^{1-6}$ Examination of family pedigrees points to an autosomal dominant pattern of inheritance, with the syndrome being distinguished from sporadic colorectal cancer by the young age of onset of malignancy. Cancers show a predilection for the right colon. It has been estimated that $5 \%$ of colorectal cancers arise through the inheritance of a dominantly acting gene, ${ }^{7}$ and it has been suggested that screening for large bowel cancer should be targeted towards individuals with a family history suggestive of HNPCC. ${ }^{58}$ While this represents a relatively small high risk group, the potential loss of years of life is relatively great in view of the young age of onset of cancer. An important additional feature of the syndrome is the increased frequency of certain extracolorectal malignancies, notably of uterus, ovary, breast, stomach, and small intestine. ${ }^{910}$ Notwithstanding the body of data relating to HNPCC, there is little information available on the pathogenesis of cancer. It is important to establish the nature of precancerous lesions, if any, as this will have a bearing on the design of preventive strategies. This study aimed to compare the prevalence and histopathology of adenomas in affected members of HNPCC families with an autopsy population in an attempt to understand the role of adenoma in the evolution of HNPCC.

\section{Patients and methods}

For the purposes of this study, the minimum criteria defining a family with HNPCC were at least three relatives (one of these being a first degree relative of the other two) with colorectal cancer implicating at least two successive generations. Clinical and pathology details of affected families are held in a registry whose function has been approved by the Auckland Hospital Research Ethics Committee. Ascertainment of patients was through receiving reports of a strong family history of colorectal cancer. One of the families has been documented previously."

The study was based on 23 patients from four
Department of Pathology, University of Auckland School of Medicine, Auckland, New Zealand J R Jass S M Stewart

Correspondence to: Professor J R Jass, Department of Pathology, University of Auckland Schoo of Medicine, Private Bag, Auckland, New Zealand.

Accepted for publication 22 July 1991
TABLE I Clinical and pathological features of adenocarcinoma in HNPCC patients

\begin{tabular}{|c|c|c|c|c|c|c|c|c|c|c|c|c|}
\hline $\begin{array}{l}P t \\
\text { no }\end{array}$ & $\begin{array}{l}\text { Fam } \\
\text { no }\end{array}$ & Sex & $\begin{array}{l}\text { Age at } \\
\text { diagnosis } \\
\text { (yrs) }\end{array}$ & $\begin{array}{l}\text { Diff } \\
W / M / P\end{array}$ & $\operatorname{Exp}$ & $\begin{array}{l}\text { Mucinous } \\
c a\end{array}$ & Site & $\begin{array}{l}\text { Stage } \\
\text { (Dukes's) }\end{array}$ & $\begin{array}{l}\text { Synch } \\
\text { ca }\end{array}$ & $\begin{array}{l}\text { Metach } \\
c a^{\star \star}\end{array}$ & $\begin{array}{l}\text { Synch } \\
\text { ad }\end{array}$ & $\begin{array}{l}\text { Metach } \\
\text { ad }\end{array}$ \\
\hline 1 & 1 & F & 35 & M & + & - & RC & B & - & - & - & - \\
\hline 2 & 1 & M & 39 & $\mathrm{~W}$ & + & - & LC & B & - & $\mathrm{R} 17$ & - & + \\
\hline 3 & 1 & M & 29 & $\mathbf{M}$ & + & - & RC & B & - & - & - & - \\
\hline 4 & 1 & $M$ & 34 & $\mathrm{P}$ & + & - & LC & B & - & - & - & - \\
\hline 5 & 1 & M & 24 & $P$ & + & + & $\mathrm{RC}$ & A & - & - & - & - \\
\hline 6 & 1 & $M$ & 29 & M & + & + & $\mathbf{R}$ & A & - & - & + & - \\
\hline 7 & 2 & $\mathbf{F}$ & 20 & W & + & - & $\mathrm{RC}$ & B & - & - & - & - \\
\hline 8 & 2 & $F$ & 27 & P & + & - & $\mathbf{R}$ & B & - & - & - & + \\
\hline 9 & 2 & $\mathbf{F}$ & 42 & $M$ & + & - & $\mathrm{RC}$ & B & - & R23 & - & - \\
\hline 10 & 2 & M & 36 & $P$ & + & + & RC & B & - & - & + & - \\
\hline 11 & 2 & $\mathbf{F}$ & 43 & W & + & - & RC & B & - & - & + & - \\
\hline 12 & 2 & $F$ & 64 & M & + & - & $\mathrm{RC}$ & B & $\mathrm{RC}$ & - & + & - \\
\hline 13 & 2 & $F$ & 33 & M & + & - & RC & $\mathrm{C}$ & - & - & - & - \\
\hline 14 & 2 & $\mathrm{~F}$ & 24 & W & $\star$ & + & $\mathrm{RC}$ & B & - & - & - & - \\
\hline 15 & 2 & $M$ & 49 & M & + & - & $\mathrm{RC}$ & B & - & LC7 & - & - \\
\hline 16 & 2 & $M$ & 43 & W & + & - & LC & B & - & R1 & - & - \\
\hline 17 & 2 & M & 61 & W & + & - & $\mathrm{R}$ & A & - & - & $+(2)$ & - \\
\hline 18 & 2 & M & 43 & $P$ & - & - & $\mathrm{RC}$ & C & - & - & - & - \\
\hline 19 & 2 & M & 64 & W & + & - & $\mathrm{RC}$ & B & - & - & - & - \\
\hline 20 & 2 & M & 19 & M & + & - & LC & B & - & - & - & - \\
\hline 21 & 2 & $M$ & 40 & M & + & - & $\mathrm{RC}$ & $\mathrm{C}$ & - & - & + & - \\
\hline 22 & 3 & $\mathrm{~F}$ & 37 & M & + & - & $\mathrm{RC}$ & $\mathrm{C}$ & - & - & + & - \\
\hline 23 & 4 & $\mathrm{~F}$ & 41 & $M$ & + & - & SC & C & - & - & + & - \\
\hline
\end{tabular}

Diff $=$ differentiation $-\mathrm{W}=$ well differentiated; $M=$ moderately differentiated; $P=$ poorly differentiated. Site $-\mathrm{RC}=$ right colon; $\mathrm{LC}=$ left colon; $R=$ rectum. Exp=expanding (as opposed to diffusely infiltrating) growth pattern; $c a=$ carcinoma; ad $=$ adenoma.

${ }^{\star}$ No slides available: ${ }^{\star} \star$
site and interval between diagnosis of first cancer $(\mathrm{yrs})$. 
TABLE II Distribution of carcinoma $(\%)$ in hereditary nonpolyposis colorectal cancer (HNPCC) and the general population

\begin{tabular}{llllll}
\hline & \multicolumn{2}{l}{ HNPCC } & & \multicolumn{2}{l}{$\begin{array}{l}\text { Survey of NZ } \\
\text { population } 1974-8^{15}\end{array}$} \\
\cline { 2 - 3 } Site & Men & Women & & Men & Women \\
\hline Right colon & 54 & 80 & & 29 & 40 \\
Left colon & 31 & 10 & & 29 & 29 \\
Rectum & 15 & 10 & & 42 & 31 \\
\hline
\end{tabular}

TABLE III Distribution of adenoma (no (\%)) in hereditary non-polyposis colorectal cancer (HNPCC) and an age matched autopsy population

\begin{tabular}{lll}
\hline Site & HNPCC & Autopsy \\
\hline Right colon & $4(36)$ & $42(40)$ \\
Left colon & $1(9)$ & $48(46)$ \\
Rectum & $6(55)$ & $15(14)$ \\
\hline
\end{tabular}

TABLE IV Type of adenoma in the hereditary non-polyposis colorectal cancer (HNPCC) group and an age matched autopsy population

\begin{tabular}{llll}
\hline Group & Tubular & Tubulovillous & Villous \\
\hline Autopsy & 99 & 6 & 0 \\
HNPCC & 3 & 2 & 6
\end{tabular}

$\mathrm{X}^{2}$ test, $\mathrm{p}=0.0001$.

families whose pathology records could be traced. Confirmation of histological findings was achieved in 22 . Twenty one patients were from two families and all four families were of European descent. There were 13 men and 10 women. Nine have died as a result of their bowel cancer and the remainder are alive and well.

Adenomas occurred in the initial surgical specimen, in subsequent operative specimens, or were found on endoscopic examination of the remaining large bowel. Age at discovery of the first adenoma was taken to compare prevalence with the control group. In patients without adenomas, age stratification was based on the age on the occasion of the most recent negative report. The maximum diameter of the adenoma was obtained from the histological preparation and the lesions were typed as tubular, tubulovillous, and villous according to WHO criteria. ${ }^{12}$ In addition, adenomas were graded as showing mild, moderate, or severe dysplasia. Adenocarcinomas were typed and graded according to WHO criteria ${ }^{12}$ and the invading border was classified as expanding or infiltrating. ${ }^{13}$ Staging was by the method of Dukes. ${ }^{1+}$

Colorectal specimens from 158 coronial autopsies served as a control group. The hepatic and splenic flexures were indicated with string ties and the rectum removed in continuity by dissecting down to the pelvic floor. The specimens were examined in the fresh state by the first author and all polyps were removed for histological examination. Locations of polyps were marked on a diagram. The large bowel was then returned to the body. Specimens from Maoris and Polynesians were excluded. Deaths were the result of accident, suicide, or sudden causes with no known association with bowel neoplasia. The polyps were measured after fixation and histological sections were prepared and stained with haematoxylin and eosin. Polyps were classified as adenomas, hyperplastic polyps, unclassified, and other. The unclassified polyps were small nodules with severe autolysis. Adenomas were typed as tubular, tubulovillous, and villous' ${ }^{12}$ but autolysis made the grading of dysplasia subjective.

\section{Results}

Clinical and pathological details of the patients used in this study are summarised in Table I. For the purposes of this study, right colon comprised the caecum and transverse colon and left colon extended from the splenic flexure to the rectosigmoid junction. The distribution of adenocarcinoma (excluding the smaller synchronous and all metachronous malignancies) is shown in Table II.

The distribution of adenoma in the study group is compared with the autopsy group in Table III. The autopsy series yielded 105 adenomas. Most of these were tubular and there were no pure villous types. In the study group, 8 of 11 adenomas showed a villous component and six of these were pure villous tumours (Table IV). Nine adenomas showed moderate or severe dysplasia. In the autopsy series most adenomas were less than $10 \mathrm{~mm}$ in diameter whereas the opposite was true for the study group (Table V). There were six instances of unequivocal adenoma contiguous with infiltrating adenocarcinoma in the study group.

Patients were stratified into age groups of less than 50 years, 50 to 69 years, and older than 70 years in order to compare the prevalence of adenoma in the autopsy and study groups. In this study group most adenomas presented in individuals under the age of 50 years and it was in this subset that important differences from the autopsy group could be discerned (Tables VI and VII).

\section{Discussion}

Patients included in this study seem to belong to families with the characteristics described by Lynch. ${ }^{1910}$ They were selected on the basis of a family history that would be consistent with an autosomal dominant tendency for the development of colorectal cancer. The mean age at diagnosis of cancer was low (39 years for men and 37 years for women). Other features described by Lynch were present. These included a predilection for the right colon (Table II), an increased incidence (22\%) of multiple large bowel cancer, ${ }^{16}$ and features of a relatively low tumour aggressiveness. The latter included a low cancer related mortality ( $9 / 23$ patients), relatively few Dukes's C cases (22\%), and few tumours showing a diffuse pattern of infiltration (4\%). The proportion of mucinous carcinomas was greater than expected $(18 \%),{ }^{13}$ supporting the findings of Mecklin et al. ${ }^{17}$ However, the proportion of carcinomas according to grade of differentiation was as expected. ${ }^{13}$ In keeping with kindreds described by Lynch, ${ }^{911}$ particular extracolonic malignancies occurred, including two endometrial carcinomas in patients with colorectal cancer as well as endometrial carcinomas (3), ovarian tumours (2), breast carcinoma (1), gastric in the hereditary nonmatched autopsy population Autopsy $97 \quad 8$

$\mathrm{x}^{2}$ test, $\mathrm{p}=0.0001$. 
TABLE VI Prevalence of adenoma(s) in men in the hereditary non-polyposis colorectal cancer (HNPCC) group and an age matched autopsy population

\begin{tabular}{lcll}
\hline & $<50$ yrs & $50-69$ yrs & $70+y r s$ \\
\hline Autopsy & $\left.5 \%\left(2 / 42^{\star \star}\right)\right\}^{\star}$ & $36 \%(16 / 44)$ & $46 \%(13 / 28)$ \\
HNPCC & $30 \%(3 / 10 \dagger)$ & $66 \%(2 / 3)$ & -
\end{tabular}

$\star X^{2}$ test, $\mathrm{p}=0.015$

${ }^{\star \star}$ Mean (SD) age $33(7)$ years

tMean $(\mathrm{SD})$ age $35(9)$ years.

TABLE VII Prevalence of adenoma(s) in women in the hereditary non-polyposis colorectal cancer (HNPCC) group and an age matched autopsy population

\begin{tabular}{|c|c|c|c|}
\hline & $<50$ yrs & $50-69$ yrs & $70+y r s$ \\
\hline $\begin{array}{l}\text { Autopsy } \\
\text { HNPCC }\end{array}$ & $\left.\begin{array}{c}5 \%\left(1 / 21^{\star \star}\right) \\
44 \%(4 / 9 \dagger)\end{array}\right\}^{\star}$ & $\begin{array}{l}12 \%(1 / 8) \\
100 \%(1 / 1)\end{array}$ & $33 \%(5 / 15)$ \\
\hline
\end{tabular}

${ }^{\star} \times$ ' test, $\mathrm{p}=0.0075$

$\star \star$ Mean (SD) age $33(10)$ years.

tMean (SD) age $33(8)$ years.

carcinoma (1), and small intestinal carcinoma (1) in other family members without colorectal cancer.

Relatively little is known of the role of adenoma in the evolution of cancer in HNPCC. Lynch has previously stressed the absence of promonitory lesions, ${ }^{2}$ but recently concluded that adenomas are precursors of cancer in HNPCC. ${ }^{18}$ Although his study showed an excess of adenomas in family members, this was because 12 members of a single family had multiple adenomas, many of which were flat. Some of these families may represent variants of familial adenomatous polyposis. ${ }^{19}$ When this unusual family was excluded from the analysis, there was no difference in adenoma prevalence between the remaining Lynch syndrome patients and a control group..$^{18}$ Other endoscopic screening studies of HNPCC families have reported a high detection rate for adenoma and carcinoma in at risk patients, but have lacked a control group. ${ }^{58}$ Screening aimed specifically at families showing the characteristics of HNPCC should be distinguished from surveys based solely on a positive family history. ${ }^{20-26}$ These studies will yield a relatively heterogeneous patient sample.

Further clarification of the evolution of bowel cancer has come from detailed pathology surveys. Lovett found that patients with a positive family history of bowel cancer had more adenomas in their surgically excised specimens than patients with a negative family history. ${ }^{27}$ This survey did not deal specifically with HNPCC. A review of HNPCC families by Love showed the presence of malignant change within adenomas. ${ }^{28}$ It was noted that adenomas occurred no more frequently in HNPCC subjects than in individuals with sporadic colorectal cancer, but developed at an earlier age. Mecklin et al confirmed the similar prevalence of adenomas in hereditary and sporadic cancer specimens, but noted a high incidence of adenomas with moderate or severe dysplasia and villous features within the heredi= tary group. ${ }^{17}$

The findings of the present study are similar to those of Love ${ }^{28}$ and Mecklin et al. ${ }^{17}$ The data point to the relative rarity of adenomas in HNPCC, the tendency for adenomas to occur at an early age, the origin of carcinoma within adenoma, and the high incidence of adenomas with a villous growth pattern and moderate or severe dysplasia. In addition, the HNPCC adenomas seem to have a greater potential for growth. These findings become more significant when one heeds the inherent biases that would reduce the differences between study and control groups. These include the retrospective nature of HNPCC data, the lack of information regarding the entire colon in some HNPCC patients, the complete or partial destruction of adenoma by carcinoma in HNPCC patients, and, with respect to pathological features of adenomas, the considerably older age of the autopsy population. The single bowel examination in the control group would not bias the data in favour of the HNPCC group if it is assumed that adenomas increase in size with time. In any event, of the eight adenomas occurring in patients under 50 years, seven were found at the time of the original operation.

It is surprising that six of the 10 adenomas occurred in the rectum given the low prevalence of carcinoma at this site, particularly in men. It is possible, however, that adenomas in the right colon existed previously but were destroyed by cancer. The low prevalence of left colonic adenomas matches the low figure for carcinoma in this site, particularly in women.

The HNPCC gene seems to predispose affected individuals to the development of small numbers of aggressive adenomas at a young age. The biological differences between sporadic and HNPCC adenomas are perhaps not as great as the differences between HNPCC adenomas and those occurring in familial adenomatous polyposis. In the latter, many thousands of adenomas develop, but are slow growing, are usually tubular, and, individually, have a low malignant conversion rate. In HNPCC, adenomas are relatively uncommon and individually must have a high malignant conversion rate. It is likely that the molecular events underlying the pathogenesis of adenoma differ considerably in the three clinical scenarios of sporadic colorectal cancer, HNPCC, and familial adenomatous polyposis. ${ }^{29}$ These differences could be in the mutations themselves or as a result of a different order of mutational steps. The inherited gene in HNPCC may be a critical and rate limiting step and its constitutional presence would thus accelerate the evolution of adenoma. It is likely to be a tumour suppressor gene that would produce no effect until the homologous gene had been lost through a mechanism such as mitotic non-disjunction. ${ }^{30}$ This would account for the focal nature of neoplastic change in HNPCC.

The above suggestions are speculative but fit well with the pathological observations described. The findings support the need for adenoma surveillance in HNPCC but point to the possibility of rapid evolution which would necessitate short interval screening in this group of patients.

This study was supported through grants from the Cancer Society of New Zealand and the Auckland Medical Research Foundation. The data could not have been collected without the help of The data could not have been collected without the help of
clinicians and pathologists in New Zealand, Australia, and Great Britain, to whom we express our gratitude. 
1 Lynch HT, Krush AJ. Heredity and adenocarcinoma of the colon. Gastroenterology 1967; 53:517-27.

2 Lynch HT, Schuelke GS, Kimberling WJ, Albano WA, Lynch JF, Biscone KA, et al. Hereditary non-polyposis colorectal cancer (Lynch syndromes I and II). II. Biomarker studies. Cancer 198

3 Mecklin J-P, Järvinen $\mathrm{HJ}$. Clinical features of colorectal carcinoma in cancer family syndrome. Dis Colon Rectum 1986; $29: 160-4$

4 Mecklin JP, Järvinen HJ, Peltokallio P. Cancer family syndrome. Genetic analysis of 22 Finnish kindreds. Gastroenterology 1986; 90: 328 .

5 Vasen HFA, den Hartog-Jager FCA, Menko FH. Screening for hereditary non-polyposis colorectal cancer: A Study of 22 Kindreds in the Netherlands. Am $\mathcal{F}$ Med 1989; 86: 278-81.

6 Cameron BH, Fitzgerald GWN, Cox J. Hereditary sitespecific colon cancer in a Canadian kindred. Can Med Assoc $\mathcal{F}$ specific colon casce

7 Mecklin J-P. Frequency of hereditary colorectal cancer. Gastroenterology 1987; 93: 1021-5.

8 Mecklin J-P, Järvinen HJ, Aukee S, Elomaa I, Karjalainen K. Screening for colorectal cancer family syndrome kindreds. Scand 7 Gastroenterol 1987; 22: 449-53.

9 Lynch HT, Kimberling W, Albano WA, Lynch JF, Biscone K, Schuelke GS, et al. Hereditary non-polyposis colorectal cancer (Lynch syndromes I and II). I. Clinical description of resource. Cancer 1985; 56: 934-8.

10 Lynch HT, Smyrk TC, Lynch PM, Lanspa SJ, Boman BM, Ens J, et al. Adenocarcinoma of the small bowel in Lynch syndrome II. Cancer 1989; 64: 2178-83.

11 Innes CB. A family with a high incidence of cancer. NZ Med F $1978 ; 87: 280-2$

12 Jass JR, Sobin LH. Histological typing of intestinal tumours. Berlin: Springer-Verlag, 1989.

13 Jass JR, Atkin WS, Cuzick J, Bussey HJR, Morson BC, Northover JMA, et al. The grading of rectal cancer: historical perspectives and a multivariate analysis of 447 cases. Histopathology 1986; 10: 437-59.

14 Dukes CE. The classification of cancer of the rectum. 7 Pathol Bacteriol 1932; 35: 323-32.

15 Jass JR. Subsite distribution and incidence of colorectal cancer in New Zealand 1974-1983. Dis Colon Rectum 1991; 34: 56-9.

16 Moertel CG, Bargen JA, Dockerty MB. Multiple carcinomas of the large intestine. A review of the literature and a study of 261 cases. Gastroenterology 1958; 34: 85-8.
17 Mecklin J-P, Sipponen P, Järvinen HJ. Histopathology of colorectal carcinomas and adenomas in cancer family syndrome. Dis Colon Rectum 1986; 29: 849-53.

18 Lanspa SJ, Lynch HT, Smyrk TC, Strayhorn P, Watson P, Lynch JF, et al. Colorectal adenomas in the Lynch syndromes. Results of a colonoscopy screening program. Gastroenterology 1990; 98: 1117-22.

19 Leppert M, Burt R, Hughes JP, Samowitz W, Nakamura Y, Woodward S, et al. Genetic analysis of an inherited predisposition to colon cancer in a family with a variable number of adenomatous polyps. $N$ Engl f Med 1990; 322: 904-8.

20 Duncan JL, Kyle J. Family incidence of carcinoma of the colon and rectum in north-east Scotland. Gut 1982; 23 169-71.

21 Burt RW, Bishop T, Cannon LA, Dowdle MA, Lee RG Skolnick $M H$. Dominant inheritance of adenomatous colonic polyps and colorectal cancer. $N$ Engl $\mathcal{F}$ Med 1985; 312: polyps and

22 Rozen P, Fireman Z, Figer A, Legum C, Ron E, Lynch HT Family history of colorectal cancer as a marker of potentia malignancy within a screening programme. Cancer 1987; 60: 248-54.

23 Fisher G, Armstrong B. Familial colorectal cancer and the screening of family members. Med F Aust 1989; 150: 22-5.

$24 \mathrm{McC}$ Connell JC, Nizin JS, Slade MS. Colonoscopy in patients with a primary family history of colon cancer. Dis Colon Rectum 1990; 33: 105-7.

25 Baker JW, Gathright JB, Timmcke AE, Hicks TC, Ferrari RT, Ray JE. Colonoscopic screening of asymptomatic patients with a family history of colon cancer. Dis Colo Rectum 1990; 33: 926-30.

26 Houlston RS, Murday V, Harocopos C, Williams CB, Slack J. Screening and genetic counselling for relatives of patients with colorectal cancer in a family cancer clinic. BMF 1990 ; 301: 366-8.

27 Lovett $\mathrm{E}$. Family studies in cancer of the colon and rectum. $\mathrm{Br}$ I Surg 1976; 63: 13-8.

28 Love RR. Adenomas are precursor lesions for malignant growth in non-polyposis hereditary carcinoma of the colon and rectum. Surg Gynecol Obstet 1986;162: 8-12.

29 Paraskeva C, Williams AC. Are different events involved in the development of sporadic versus hereditary tumours? The possible importance of the microenvironment in hereditary cancer. Br f Cancer 1990; 61: 828-30.

30 Solomon E. colorectal cancer genes. Nature $1990 ; 343: 412-4$. 